Case Report

\title{
An Accidental Intestinal Myiasis Caused by Cochliomyia macellaria
}

\author{
P. P. Jayawardana $\mathbb{D}^{1}$ and T. C. Yahathugoda ${ }^{2}$ \\ ${ }^{1}$ Department of Pediatrics, Faculty of Medicine, University of Ruhuna, Matara, Sri Lanka \\ ${ }^{2}$ Department of Parasitology Faculty of Medicine, University of Ruhuna, Matara, Sri Lanka
}

Correspondence should be addressed to P. P. Jayawardana; pushpikaja@yahoo.com.au

Received 7 November 2020; Revised 3 February 2021; Accepted 6 February 2021; Published 16 February 2021

Academic Editor: Ozgur Kasapcopur

Copyright (C) 2021 P. P. Jayawardana and T. C. Yahathugoda. This is an open access article distributed under the Creative Commons Attribution License, which permits unrestricted use, distribution, and reproduction in any medium, provided the original work is properly cited.

\begin{abstract}
Intestinal myiasis is recognized as pseudomyiasis or accidental myiasis caused by dipteran fly larvae transmitted to humans via contaminated food or water. A case of intestinal myiasis acquired via contaminated food is reported in this case study. The patient is a 4-year-old boy who had frequent episodes of crampy abdominal pain and diarrhoea and the passage of many live worms at each time. As the child had the habit of eating ripe guava from his garden, the infection source was suggested as ripe guava, and the possibility was explored. All larvae collected from faeces and fruit were morphologically similar, and it has been identified as Cochliomyia macellaria. The treatment with several antihelmintics failed, and the recovery was achieved with a simple measure of abstinence from eating guava that came from his garden.
\end{abstract}

\section{Introduction}

Infestation of live human or any vertebrate host with dipteran fly larvae is called myiasis [1]. Human myiasis can manifest as cutaneous myiasis, wound myiasis, oracular myiasis, and nasopharyngeal myiasis in common; however, anal myiasis, body cavity myiasis, aural myiasis, and intestinal myiasis are also reported [2]. Myiasis is classified into facultative, obligatory, and accidental categories depending on their survival on dead or live tissue. Fly larvae that requires living tissue for their survival cause obligatory myiasis. In contrast, those who live on dead or necrotic tissue cause facultative myiasis. The fly larvae that are accidentally ingested or deposited on living tissue cause accidental myiasis [1].

The first report on human myiasis in Sri Lanka was published in 1954 [3]. Only a limited number of indigenous cases were published to date [4-7]. Cutaneous myiasis was the commonest form, and Chrysomya bezziana (Old world screwworm fly) and C. megacephala were documented fly larvae $[3,6,7]$. Cordylobia anthropophaga (tumbu fly) was also reported in Sri Lanka as imported cases of cutaneous myiasis [8,9]. Other common myiasis-causing agents such as Cochliomyia hominivorax (New world screwworm fly) and Sarcophaga spp. (flesh fly or sarcophagids) are not documented in Sri Lanka $[7,10]$.

People who have low socioeconomic conditions and live in a poor hygienic environment are at a risk of developing myiasis [10]. Intestinal myiasis or pseudomyiasis or accidental myiasis caused by ingestion of dipteran fly eggs via contaminated food or water is commonly seen in such communities [11]. However, fly larval infestation is most often self-limiting and does not result in any serious complications, which is a major cause of underreporting of human myiasis throughout the world. Hitherto, a case of intestinal myiasis is not reported in Sri Lanka. Diagnosis of human myiasis is usually missed by physicians due to lack of suspicion and have little idea of the specific clinical features [1]. Therefore, this case report aims to improve physicians' knowledge of intestinal myiasis by considering intestinal myiasis in the differential diagnosis list when assessing acute and chronic abdominal pains, especially in children. 


\section{Case Presentation}

A 4-year-old previously healthy boy had several (seven) episodes of colicky abdominal pain and loose stools over ten months. These episodes were never associated with fever but have had loss of appetite and infrequent vomiting. He had perianal discomfort both in the day and night. His mother had observed the passage of live worms with faeces on all these occasions, and she emphasized that it was more than 500 in number. During this period, no one else in the family had an illness similar to food poisoning, gastroenteritis, or worm infestation.

He was first seen by a general practitioner and treated for a common intestinal helminthiasis with mebendazole $100 \mathrm{mg}$ twice daily for three days without obtaining laboratory evidence. After that, the child had been seen five times by general practitioners before the first author saw him. Stool investigations were done on two occasions and were reported as normal. It was not easy to get the treatment history due to retrograde exploration. The child had been treated with various anthelmintics and antibiotics. His mother could recall that he had been given both anthelmintics and antibiotics in a combination in few occasions. He had been treated with mebendazole $100 \mathrm{mg}$ twice daily for three days in two occasions, albendazole $400 \mathrm{mg}$ single dose in two occasions, and once treated by two tablets of pyrantel pamoate $(250 \mathrm{mg})$. Whenever those episodes were predicted as food poisoning or infective gastroenteritis, the child had received either cephalexin or metronidazole along with zinc and probiotics for 3-5 days. Usually, the child became symptom-free in 6-7 days regardless of the treatment modality, but the reappearance of the symptoms in few weeks were inevitable.

The first author has seen the child in his sixth episode. The child complained of a gush of offensive loose stools with worms and abdominal cramps. A sample of stool has been sent for amoeba, ova, and cysts but became negative. Fecal culture was negative for bacteria. However, the child was treated empirically for helminthic infection using $400 \mathrm{mg}$ albendazole single dose and repeated the same dose of treatment after a week. All family members were treated with the same regimen and instructed to follow hygienic measures. The child was brought to the same clinic in few weeks due to reappearance of similar symptoms. This occasion, the faeces were frothy and greenish. The parents have taken all possible hygienic measures to prevent the recurrences by introducing regular hand washing, cutting nails short etc. However, it did not prevent him getting recurrences.

He was from a semiurban area. In his garden, there were many guava trees bearing fruits. He had the habit of eating ripe guava. Upon the authors' request, the parents collected a fecal sample and guava fruit with larvae (Figure 1). The parents succeeded in taking video-clips of live worms on faeces and fruits.

The second author examined all samples at the Department of Parasitology, Faculty of Medicine, University of Ruhuna. Live specimens were found in faeces and fruits. Faeces was examined using saline, iodine wet mounts, and Kato-Katz. It was negative for amoeba, ova, and cysts.

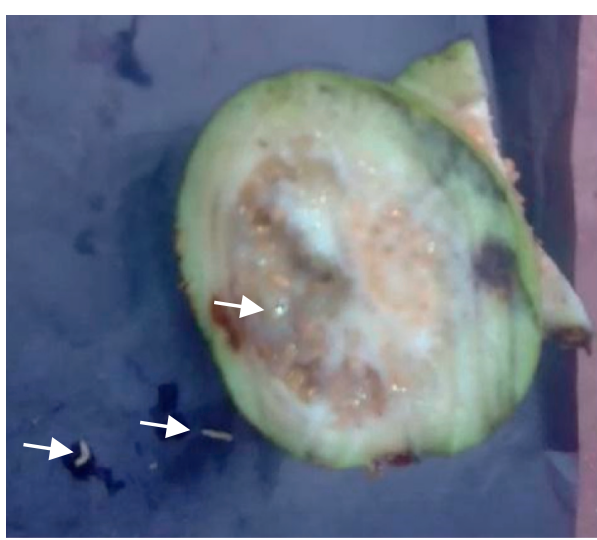

Figure 1: Guava fruit with fly larvae.

Live wormy specimens were submerged in hot water $\left(\sim 95^{\circ} \mathrm{C}\right)$ for 30 seconds and then in $95 \%$ ethanol before examining them under a dissecting microscope. The average length of larvae was $7 \mathrm{~mm}$.

2.1. Microscopic Identification of Larvae. Pictorial key of Centers for Disease Control and Prevention, USA, was referred for larval identification (http://www.cdc.gov). All specimens collected did not have a definite, hard, sclerotized head capsule. The body was smooth and had short spines but no long lateral processes. Posterior spiracles were not on peg-like tubercles (Figure 2). Body was tapered posteriorly but did not extend into a tail-like process. Dissected posterior spiracle showed peritreme with three distinct slits which were positioned straight (Figure 3). The dorsal arm of cephaloskeleton is longer than the ventral arm and posterior spiracles with incomplete peritreme (Figures 3 and 4).

Spiracle slits point towards opening in peritreme (Figure 3). Prothoracic spiracles had 15 openings (Figure 5). Posterior spiracle button is indistinct, and wall of slits had swellings (Figure 3). Tracheal trunks were not pigmented (Figure 5). Larvae have been identified as Cochliomyia macellaria. All larvae collected from faeces and fruit were morphologically similar.

The parents were instructed to avoid possible exposure to eating fruits (guava) from their garden. The child was reviewed in 3 and 6 months. He was symptom-free, and larvae have ceased appearing in the faeces.

\section{Discussion}

A careful evaluation of fly larvae collected from the child's faeces and the fruit revealed that the both larval groups were morphologically similar, and the key described by the Centers for Disease Control and Prevention, USA (http:// www.cdc.gov), identified the larvae as Cochliomyia macellaria (secondary screwworm). Intestinal myiasis caused by Cochliomyia macellaria (secondary screwworm) is new to world literature. Myiasis due to Cochliomyia hominivorax (New world screwworm) is well documented. Cochliomyia hominivorax is an obligatory parasite causing intestinal [12], auricular [13], oral [14], nasal [15], and wound [16] myiasis. 


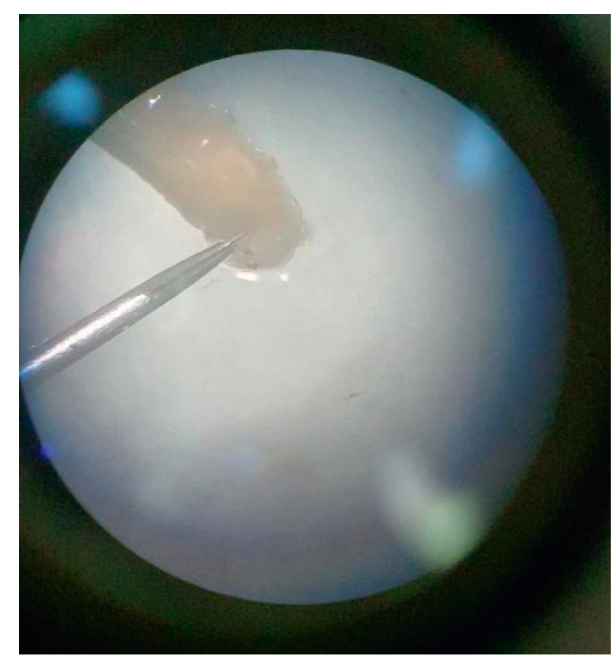

Figure 2: Posterior spiracles (before dissect).

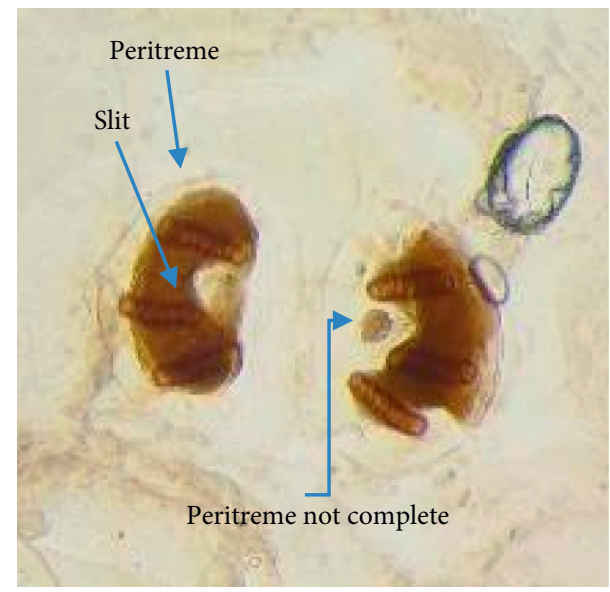

FIgURE 3: Posterior spiracles (after dissect).

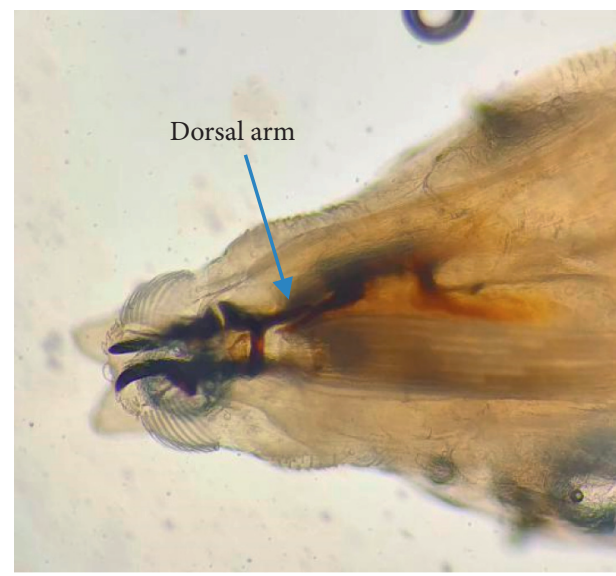

Figure 4: Arms of cephaloskeleton.

Cochliomyia macellaria is a facultative parasite that infests on wound or necrotic tissue of man and livestock. Like C. hominivorax, C. macellaria does not feed on living tissues [17]. Livestock industry experiences huge economic losses due to parasitism (myiasis) and disease transmission caused

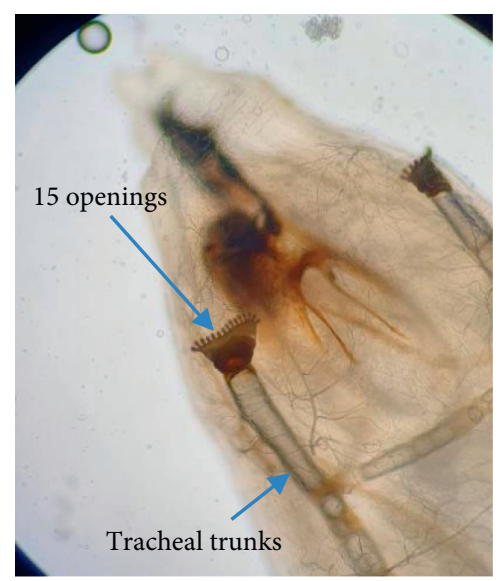

FIGURE 5: Prothoracic spiracles.

by C. macellaria maggots. Different salmonella types, swine flu, and botulism in birds are transmitted by maggots of C. macellaria [17].

All reported cases of intestinal myiasis have caused only by facultative or accidental fly larvae, whereas obligatory gut parasites of animals have never been encountered in human gut [18].

Over 50 species of fly larvae mainly belonging to families Muscidae, Calliphoridae, and Sacrophagidae have been reported from cases of intestinal myiasis. The clinical presentations of enteric myiasis reported so far and their site of infestation and species identified are summarized in Table 1.

The child has had more than three episodes of abdominal pain within three months; therefore, the presentation can be considered as recurrent abdominal pain (RAP) in children [39]. Diagnosis of RAP depends on the clear history provided by the parent and the child. The common causes of RAP such as functional abdominal pain, constipation, irritable bowel, and peptic ulcers could be diagnosed clinically by taking a careful history and through physical examination [40]. Intestinal infections due to bacteria, protozoa, and helminths can be diagnosed by a direct stool examination and culture. RAP in Sri Lanka is most considered as functional abdominal pain (nonorganic) where associated symptoms such as fever, vomiting, and microorganism or blood in stool are not seen $[39,41]$. Here, in this case, the child has experienced several episodes of vomiting, diarrhoea, and perianal discomfort other than the vague abdominal pain. Therefore, an organic cause was considered for the RAP, and the child was investigated with stool AOC and culture. Since none of the investigation became positive, an empiric cause of medical management was considered because it has greater value than multiple exclusionary investigations [40].

Intestinal myiasis is also considered as an organic cause for RAP [39]. Simple elimination of eating guava has improved the child's clinical condition. Therefore, we can assume that the symptoms mentioned above were due to 'maggots' infestation, but it is an incontestable proof. Offensive greenish stools associated with colicky abdominal 
TABle 1: Clinical presentation, site of infestation, and the species of fly larvae in reported cases of enteric myiasis.

\begin{tabular}{|c|c|c|c|}
\hline Clinical details & $\begin{array}{c}\text { Affected } \\
\text { area }\end{array}$ & Species & Reference \\
\hline $\begin{array}{l}\text { Seven cases were reported with passage of worms from } 3 \text { months to } 6 \text { years, } \\
\text { vague abdominal discomfort, diarrhoea, and anaemia }\end{array}$ & Intestine & $\begin{array}{l}\text { Sarcophaga haemorrhoidalis (4) } \\
\text { Sarcophaga spp. (1) } \\
\text { Magaselia spp. (1) } \\
\text { Muscina stabulans (1) }\end{array}$ & {$[18]$} \\
\hline $\begin{array}{l}\text { Comorbidity with intestinal myiasis and helminthic infection } \\
\text { Passage of live worms in stool } \\
\text { Comorbidity with intestinal myiasis and giardiasis }\end{array}$ & $\begin{array}{l}\text { Intestine } \\
\text { Intestine } \\
\text { Intestine }\end{array}$ & $\begin{array}{l}\text { Sarcophaga haemorrhoidalis } \\
\text { Sarcophaga spp. } \\
\text { Sarcophaga spp. }\end{array}$ & $\begin{array}{l}{[19]} \\
{[20]} \\
{[21]}\end{array}$ \\
\hline $\begin{array}{l}\text { Three cases were presented: one case had comorbidity with Salmonella } \\
\text { enteritis, and two other cases had asymptomatic passage of worms }\end{array}$ & Intestine & $\begin{array}{l}\text { Sarcophaga crassipalpis (carrier of } \\
\text { Salmonella) }(1) \\
\text { Sarcophaga peregrina }(1) \\
\text { Hermetia illucens }(1)\end{array}$ & {$[22]$} \\
\hline $\begin{array}{l}\text { Presented with vague abdominal pain and irritable bowel } \\
\text { Passage of worms in stool } \\
\text { Two cases were reported: passage of worms in stool } \\
\text { Passage of worms in stool } \\
\text { An irritable child was passing blood and mucous diarrhoea } \\
\text { Passage of worms in stool after consuming overripe banana } \\
\text { Passage of worms in stool after consuming overripe decaying peaches }\end{array}$ & $\begin{array}{l}\text { Intestine } \\
\text { Intestine } \\
\text { Intestine } \\
\text { Intestine } \\
\text { Intestine } \\
\text { Intestine } \\
\text { Intestine }\end{array}$ & $\begin{array}{l}\text { Muscina stabulans } \\
\text { Megaselia scalaris } \\
\text { Musca domestica } \\
\text { Eristalis Tenax } \\
\text { Sarcophaga peregrina } \\
\text { Muscina stabulans } \\
\text { Eristalis tenax } \\
\end{array}$ & $\begin{array}{c}{[23]} \\
{[24,25]} \\
{[26]} \\
{[27-30]} \\
{[31]} \\
{[32]} \\
{[33]} \\
\end{array}$ \\
\hline $\begin{array}{l}\text { Four cases were presented: three had offensive hematemesis and minute } \\
\text { moving worms in the vomitus, and the other one had symptomatic passage of } \\
\text { worms in stool }\end{array}$ & $\begin{array}{l}\text { Gastric (3) } \\
\text { Intestine } \\
(1)\end{array}$ & $\begin{array}{l}\text { Sarcophaga spp. (2) } \\
\text { Oestrus spp. (2) }\end{array}$ & [34] \\
\hline $\begin{array}{l}\text { Passage of worms in stool } \\
\text { Passage of worms in stool } \\
\text { Passage of worms in stool }\end{array}$ & $\begin{array}{l}\text { Intestinal } \\
\text { Intestinal } \\
\text { Intestinal } \\
\end{array}$ & $\begin{array}{c}\text { Fannia canicularis } \\
\text { Hermetia illucens } \\
\text { Phaenicia cuprina }\end{array}$ & $\begin{array}{c}35] \\
{[36,37]} \\
{[38]}\end{array}$ \\
\hline
\end{tabular}

pain and vomiting may have been triggered by the inflammation caused by fly maggots [16]. Similar offensive breath and vomit has been reported due to gastric myiasis [34], (Table 1). Consumption of overripe or rotten fruits such as banana [32] and peach [33] has triggered intestinal myiasis (Table 1). Confirmation of transmission route by demonstrating the same species of fly larvae in guava fruit is a remarkable achievement. For the first time in Sri Lanka, such transmission route is established and for the first time in the world literature, guava as the fruit to transport fly eggs larvae. Studies conducted in Sri Lanka have documented Megaselia scalaris in ripe bananas; however, intestinal myiasis caused by them has not been reported [42].

There is no specific treatment for intestinal myiasis [18]. Anti-inflammatory and antiperistaltic agents will reduce the symptoms, whereas broad-spectrum anthelmintics and antibiotics will not be helpful. Therefore, conducting continuous education and communications programmes to improve the knowledge of prevention and precautions against intestinal myiasis for physicians and public health officials is needed. Success will be based on behavioral modification such as abstain from consuming uncovered food, which has access to fly, and overripe or rotten fruits and abstain from defecating in the open. We want to emphasize that clinicians must find species and transmission route before embarking on the therapy. The only successful treatment for enteric myiasis was colonic irrigation using oral polyethylene glycol (PEG) [18]. Ivermectin was tried with no significant effect [18].

\section{Conclusion}

Though the intestinal myiasis does not cause serious complication, the morbidity is substantial. Therefore, a great deal of suspicion and exploring a history of passage of worms will diagnose intestinal myiasis. Identification of the species and the route of transmission is of profound importance to eliminate the disease.

\section{Data Availability}

The data used to support the finding of this study are included within the article.

\section{Consent}

Written informed consent for the publication has been obtained from both parents of the child.

\section{Conflicts of Interest}

The authors declare that they have no conflicts of interest.

\section{References}

[1] K. V. Ramana, "Human myiasis," Journal of Medical Microbiology \& Diagnosis, vol. 1, no. 2, p. e105, 2012.

[2] E. D. Palmer, "Entomology of the gastrointestinal tract: a brief review," Military Medicine, vol. 135, no. 3, pp. 165-176, 1970.

[3] H. G. A. Bayer, "Myiasis maligna of nose and ears in ceylon: recommendation of a new treatment," Archives of 
Otolaryngology-Head and Neck Surgery, vol. 59, no. 1, pp. 104-107, 1954.

[4] N. R. De Silva and D. Madagedera, "Wound myiasis due to Chrysomya bezziana: a case report," Kandy Medical Journal, vol. 1, pp. 75-76, 1992.

[5] C. A. Jacobi, C. Bruns, and H. W. Keller, "Myiasis of the scalp-an incidental finding in ambulatory surgery," Zentralblatt Fur Chirurgie, vol. 119, no. 10, pp. 733-735, 1994.

[6] S. P. W. Kumarasinghe, N. D. Karunaweera, and R. L. Ihalamulla, "A study of cutaneous myiasis in Sri Lanka," International Journal of Dermatology, vol. 39, no. 9, pp. 689-694, 2000.

[7] Y. T. B. Bambaradeniya, W. A. I. P. Karunaratne, S. V. Rakinawasam et al., "Myiasis incidences reported in and around central province of Sri Lanka," International Journal of Dermatology, vol. 58, no. 3, pp. 336-342, 2019.

[8] J. S. Edirisinghe and C. Rajapakshe, "Myiasis due to Cordylobia anthropophaga the tumbufly in a Sri Lankan infant," Ceylon Medical Journal, vol. 36, pp. 112-115, 1991.

[9] T. D. S. Naotunna, M. M. Ismail, and R. L. Ihalamulla, "The second case of cutaneous myiasis caused by Cordylobia anthropophaga (Tumbufly) in Sri Lanka," Ceylon Journal of Medical Sciences, vol. 43, pp. 31-33, 2000.

[10] M. Hall and R. Wall, "Myiasis of humans and domestic animals," Advances in Parasitology, vol. 35, p. 257, 1995.

[11] M. F. Ferreira, K. K. Ieng, L. Claro, G. W. Chau, S. Shinonaga, and T. Goto, "Intestinal myiasis in Macao," Chinese Journal of Parasitology \& Parasitic Diseases, vol. 8, no. 3, pp. 214-216, 1990.

[12] V. Kandi, S. Lal, K. Sandhya et al., "Persistent pediatric gastrointestinal myiasis: a case report of fly larval infestation with musca domestica with review of literature," Journal of Global Infectious Diseases, vol. 5, no. 3, pp. 114-117, 2013.

[13] I. Al Jabr, "Aural myiasis, a rare cause of earache," Case Reports in Otolaryngology, vol. 2015, Article ID 219529, 3 pages, 2015.

[14] J. P. Novo-Neto, F. De Sant'Ana dos Santos, A. E. Farias Pontes, F. S. Ribeiro, F. L. F. Scannavino, and A. T. Martins, "Oral myiasis caused by Cochliomyia hominivorax in a disabled person," Case Reports in Pathology, vol. 2015, Article ID 904658, 3 pages, 2015 .

[15] R. Tai, M. A. Marsh, R. Rao, P. C. Kurniali, E. DiNino, and J. V. Meharg, "Nasal myiasis caused by Cochliomyia hominivorax in the United States: a case report," American Journal of Infectious Diseases, vol. 7, no. 4, pp. 107-109, 2011.

[16] F. Francesconi and O. Lupi, "Myiasis," Clinical Microbiology Reviews, vol. 25, no. 1, pp. 79-105, 2012.

[17] J. H. Byrd, Featured Creatures-Entomology \& Nematology, University of Florida, Gainesville, FL, USA, 2020, http://entnemdept. ufl.edu/CREATURES/livestock/secondary_screwworm.htm.

[18] U. Udgaonkar, S. Kulkarni, S. Patil et al., "Intestinal myiasis," Indian Journal of Medical Microbiology, vol. 30, no. 3, pp. 332-337, 2012.

[19] P. R. Atal and D. C. Dubey, "Intestinal myiasis with accompanying helminthic infestations," Journal of The Indian Medical Association, vol. 41, pp. 403-405, 1963.

[20] A. Das, A. Pandey, M. Madan, A. K. Asthana, and A. Gautam, "Accidental intestinal myiasis caused by genus Sarcophaga," Indian Journal of Medical Microbiology, vol. 28, no. 2, pp. 176-178, 2010.

[21] P. Gupta, M. Sen, V. Khare, U. Ghoshal, V. C. Ghoshal, and S. Gandhi, "Intestinal myiasis caused by genus Sarcophaga larvae coexisting with giardiasis: a case report," Indian Journal of Public Health Research \& Development, vol. 1, no. 2, pp. 79-81, 2010.
[22] K. Nagakura, Y. Kawauichi-Kato, H. Thchibana, Y. Kaneda, S. Shinonaga, and R. Kano, "Three cases of intestinal myiasis in Japan," Journal of Infectious Diseases, vol. 163, no. 5, pp. 1170-1171, 1991.

[23] S. Shivekar, K. Senthil, R. Srinivasan, L. Sureshbabu, P. Chand, and J. Shanmugam, "Intestinal myiasis caused by Muscina stabulans," Indian Journal of Medical Microbiology, vol. 26, pp. 83-85, 2008.

[24] N. B. Singh, T. K. Singh, Y. I. Singh, and M. A. Razaque, "Intestinal myiasis caused by Megaselia scalaris (Diptera: phoridae): a case report," The Journal of Communicable Diseases, vol. 20, no. 2, p. 163, 1988.

[25] S. A. Mazayad and M. M. Rifaat, "Megaselia scalaris causing human intestinal myiasis in Egypt," Journal of the Egyptian Society of Parasitology, vol. 35, no. 1, pp. 331-340, 2005.

[26] R. Sehgal, H. P. Bhatti, D. K. Bhasin et al., "Intestinal myiasis due to Musca domestica: a report of two cases," Japanese Journal of Infectious Diseases, vol. 55, no. 6, pp. 191-193, 2002.

[27] G. Scuderi, "A case of intestinal myiasis due to Eristalis tenax in man," Archivio di Medicina Interna, vol. 16, pp. 135-139, 1964.

[28] A. Aguirlera, A. Cid, B. J. Reigueiro, J. M. Preito, and M. Noya, "Intestinal myiasis caused by Eristalis tenax," Journal of Clinical Microbiology, vol. 37, p. 3082, 1999.

[29] A. Clavel, M. Totedo, P. Goni, and G. Aspiroz, "Intestinal myiasis due to Eristalis tenax: report of new case in Spain," New Microbiologica, vol. 34, no. 3, pp. 335-336, 2011.

[30] M. Kun, A. Kreiter, and L. Semenas, "Myiasis gastrointestinal humana por Eristalis tenax," Revista de Saúde Pública, vol. 32, no. 4, pp. 367-369, 1998.

[31] S. Hasegawa, H. Miwata, S. Masuda, H. Naruse, and T. Ozaki, "An infantile case of intestinal myiasis," Pediatrics International, vol. 34, no. 1, pp. 87-89, 1992.

[32] D. E. North, K. L. Matteson, S. D. Helgerson et al., "Intestinal myiasis in a baby attending a public health clinic," The Nurse Practitioner, vol. 12, no. 5, pp. 60-62, 1987.

[33] M. Hall and J. T. Muir, "A critical study of a case of myiasis due to Eristalis," Archives of Internal Medicine, vol. 11, no. 2, pp. 193-203, 1913.

[34] A. K. Ahmad, E. H. Abdel-Hafeez, M. Makhloof, and E. M. Abdel-Raheem, "Gastrointestinal myiasis by larvae of Sarcophagasp and Oestrussp in Egypt: report of cases, and endoscopical and morphological studies," The Korean Journal of Parasitology, vol. 49, no. 1, pp. 51-57, 2011.

[35] Z. R. Yang, D. W. Bao, and X. Y. Liang, "Gastric myiasis caused by the larvae of Fannia canicularis," Chinese Journal of Parasitology \& Parasitic Diseases, vol. 23, no. 4, p. 216, 2005.

[36] O. Calderón-Arguedas, J. Murillo Barrantes, and M. E. Solano, "Enteric myiasis by Hermetia illucens (Diptera: stratiomyidae) in a geriatric patient of Costa Rica," Parasitología Latinoamericana, vol. 60, no. 3-4, pp. 162-164, 2005.

[37] O. F. González and G. R. Oliva, "First report of intestinal myiasis caused by Hermetia illucens (Diptera: stratiomyidae)," Revista Cubana de Medicina Tropical, vol. 61, no. 1, pp. 97-99, 2009.

[38] A. J. Morris and M. A. Berry, "Intestinal myiasis with Phaenicia cuprina," American Journal of Gastroenterology, vol. 91, no. 6, p. 1290, 1996

[39] A. M. Lake, "Chronic abdominal pain in childhood: diagnosis and management," American Family Physician, vol. 59, no. 7, pp. 1823-1830, 1999.

[40] C. E. Reust and A. Williams, "Recurrent abdominal pain in children," American Family Physician, vol. 97, no. 12, pp. 785-793, 2018. 
[41] S. Rajindrajith, J. Zeevenhooven, N. M. Devanarayana, B. J. C. Perera, and M. A. Benninga, "Functional abdominal pain disorders in children," Expert Review of Gastroenterology \& Hepatology, vol. 12, no. 4, pp. 369-390, 2018.

[42] N. D. Karunaweera, R. L. Ihalamulla, and S. P. Kumarasinghe, "Megaselia scalaris (Diptera: phoridae) can live on ripe bananas-a potential health hazard?" The Ceylon Medical Journal, vol. 47, no. 1, pp. 9-10, 2002. 